\title{
摩擦の異なる床仕上げ材間の識別容易性に関する研究*
}

\author{
原利 明*1，小林吉 之*2 \\ 蔵重 由貴子*3, 藤 本 浩 志*4

\section{Discriminability of Floor Dressing Materials with Different Friction While Walking} \\ Toshiaki HARA*5, Yoshiyuki KOBAYASHI, \\ Yukiko KURASHIGE and Hiroshi FUJIMOTO \\ *5 Architectural Design Division, Kajima Corporation, \\ 6-5-30 Akasaka, Minato-ku, Tokyo, 107-8502 Japan

\begin{abstract}
This study examined how accurately people can discriminate differences in the friction of flooring samples. Flooring samples of either different friction or elasticities were presented by placing two walking boards made of plywood, each surfaced with one of three different flooring samples, in an end- to-end fashion. Ten young adults whose sight was temporarily cut off by eye masks were asked to walk on the path for 108 trials and indicate whether the flooring samples were different or not. Generally, the percentages of correct answers for the pairs of flooring samples with different frictions were low compared with the percentages of correct answers for the pairs of flooring samples with different elasticity. However, the subjects who scuffed their heel on the ground prior to step on to the samples discriminated the differences fairly accurately, even for the materials with different frictions.
\end{abstract}

Key Words: Human Engineering, Human Interface, Medical and Welfare Assistance

\section{1. 緒 論}

視覚障害者誘導用ブロック（以下，誘導ブロック という）は，視覚障害者を対象とした移動支援の一 つとして我が国で 1967 年に考案され(1)，現在世 界各国に普及し始めている，国内では，都市・建築 の連続的なバリアフリー化を促進させることを目的 としたバリアフリー新法などの法律や各種条令の整 備により，道路や駅などの公共交通施設，公共的建 築物などを中心に誘導ブロックの敷設が促進された。 これは視覚障害者の円滑な単独歩行を支援する重要 な役割を果たしており，視覚障害者に対して行われ たアンケート調査 ${ }^{(2)}$ によると, 視覚障害者の約 7

* 原稿受付 2008 年 8 月 12 日

*I 正員, 鹿島建設(株)建築設計本部(者107-8502 東点都港区 赤坂 6-5-30)

*2 正員, 国立身体障害者リハビリテーションセンター研究所 (要 359-8555 所沢市详木 4-1)

*3 早稻田大学人間科学部(幅 359-1192 所沢市三ヶ島 2-57915).

*4 正員, 早稻田大学人間科学学術院(承359-1192 所沢市三ヶ 島 2-579-15).

E-mail : thara@kajima.com
割が誘導ブロックを歩行時の手がかりとしているこ とからその重要性が何える。しかし、現状ではバリ アフリー法によって定められている特定経路や公共 交通施設、建物においては道路から受付までなど法 律で定められている最低限の部分にしか敷設されて いない，一方で誘導ブロックの普及と共に，誘導ブ ロックを必要としない人にとってはその突起が逆に バリアになっていることも指摘され，車椅子使用者 に対して行われたアンケート調査 ${ }^{(3)}$ によると， 「車椅子と物理的環境との間に生ずる事故や危険」 を聞いた項目の中で「道路の凹凸や小石・点字ブロ ックによって事故や危険を感じたこと, 若しくは実 際に失敗したこと」が上位に上げられており，その 危険性がわかる，また，誘導ブロックが影響する車 椅子使用者だけでなく(4)(5)，晴眼者の歩行への 影響も定量的に評価されている(6) (7) (8)。

このような現状の中，近年では建築空間において 床仕上げ材間の足で感じる感触の違いを利用した方 法により，これまでの誘導ブロックによる方法では 


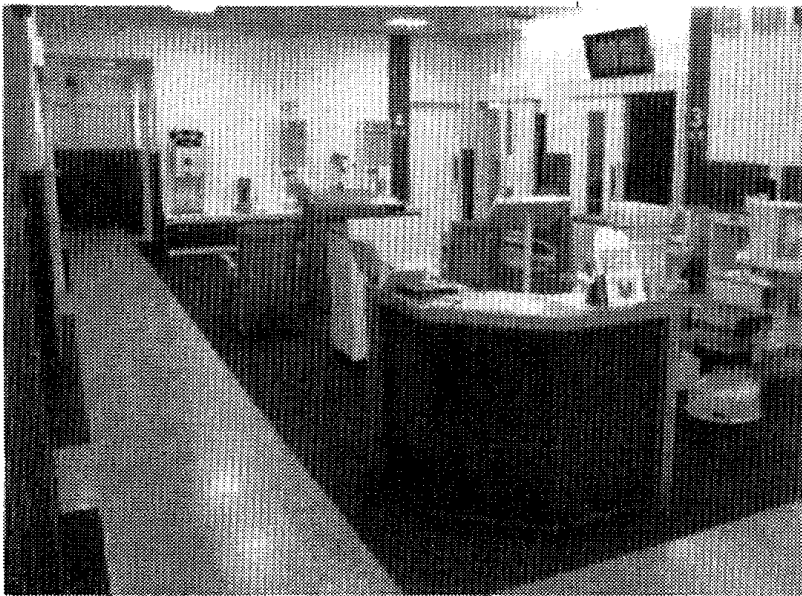

Fig. 1 Example of the case where installed different floor materials to indicate the path to visually impaired instead of ordinary indicators with convexities. (Kashiwase Optometry)

ない歩行空間の提示を図る事例がでてきている，そ の最も基本的な差の提示方法として，弾性の異なる 床仕上げ材を用いる方法があり，厚生労働省が大阪 府に整備した国際障害者交流センターをはじめいく つかの医療機関等でも既に試行されている. 図 1 は 栃木県のある眼科の事例で, 安全に歩行できるエリ アを硬い塩ビタイルとし, 家具や什器があり歩行に 注意が必要なエリアは柔らかいカーペットタイルと している.このような床仕上げ材の硬さの違いによ りエリアの違いの情報を提示することを試みている。 しかし歩行中にどの程度正確に識別できるかという 定量的な評価は示されていなかった。

このような状況から，小林らは床仕上げ材の弾性 による情報提示の可能性に着目し，情報提示を可能 とする床仕上げ材の弾性の差に関する検証を実験的 に行った ${ }^{(9)}$. その結果，ヒトは歩行中に床仕上げ 材の弾性の差を従来の誘導ブロックと同等の高い正 答率で識別することが確認された。このことから床 仕上げ材の弾性の差により視覚障害者に歩行空間を 十分提示できる可能性が示唆された。

歩行中の視覚障害者に床仕上げ材の違いによる情 報提示方法は，これまで研究を重ねてきた弾性以外 にも考えられる. 例えば建築空間の床仕上げに掞い て意匠上の観点から同一床面で同じ種類の石材の表 面を磨き平滑にしたもの（摩擦小）とバーナーなど で表面を荒らした粗面のもの（摩擦大）を組み合わ せ，空間を演出するデザイン手法もよくみられる. もしヒトが床面の摩擦差を歩行中に識別可能である ことが実証されれば，このように頻繁に用いられる
手法に単なるデザインでなく, 視覚障害者への情報 提示という機能性を付加することが可能となる。 そ のためには，摩擦の異なる床仕上げ材を歩行中にヒ トがどの程度正確に識別できるかを調べる必要があ る.そこで本研究では, 歩行中における摩擦の異な る床仕上げ材の識別容易性を客観的・定量的に評価 することを目的とする. 本研究によって床仕上げ材 間の摩擦の違いによる識別の有効性が示されれば, 先行研究の床仕上げ材の弾性による情報提示と同様 に，従来の誘導ブロックのような突起を用いずに視 覚障害者に歩行空間を提示する手法が提案でき, こ のような手法を用いることで従来の誘導ブロックが 敷設できなかった筒所へも歩行空間を提示すること が可能となり、誘導ブロックを補完することができ ると考えている.

\section{2. 方 法}

本研究を行う上での全てのプロトコールは早稲田 大学研究倫理審査委員会より承認を得た。被験者は 実験協力依頼の揭示を確認し応募してきた, 晴眼 (自己申告) の大学生 10 名 (男性 5 名, 女性 5 名, mean age 21.6, SD土1.91）とした。これは, 普段視 覚を遮蔽した状況で歩行すること, 及び床仕上げ秋 の差の識別を歩行時の手がかりとすることに慣れて いない晴眼者らが識別できる床仕上げ材の組み合わ せであれば，普段からこのような状況で床仕上げ材 を識別している視覚障害者にとってはより正確に識 別できるものとなると考えたためである. 本実験で は足底での識別容易性を評価することを目的とする ため足底以外の識別の手がかりとなり得る情報を遮 断した。 そこで被験者はアイマスクを着用し視覚情 報を遮蔽し, 歩行中の足音が床仕上げ材の差を識別 する手がかりとなることが考えられたため，ホワイ トノイズを流したヘッドホンを着用させ聴覚情報も 遮蔽した. また本研究では足底経由の床面の特徴に 限定するために白杖は用いなかった．実験中各自が 履き慣れたゴム底のスニーカを着用した。これは視 覚障害者が歩行訓練を行う際に安全性に配慮しゴム 底のスニーカを用いていることと、また底が柔らか い素材の靴の方が, 硬い素材の靴よりも床面の状況 を識別し難いと考えられ，他の要因と同様により困 難な状況での識別性を評価するために本研究ではこ のような靴の設定とした。

本研究では床仕上げ材として表面を磨いて摩擦を 小さくした御影石（松下産業 TS-0101F，以下『ミ ガキ』と記す）とバーナーで表面を粗し摩擦の大き な御影石（松下産業 TS-0201F，以下『バーナー』 


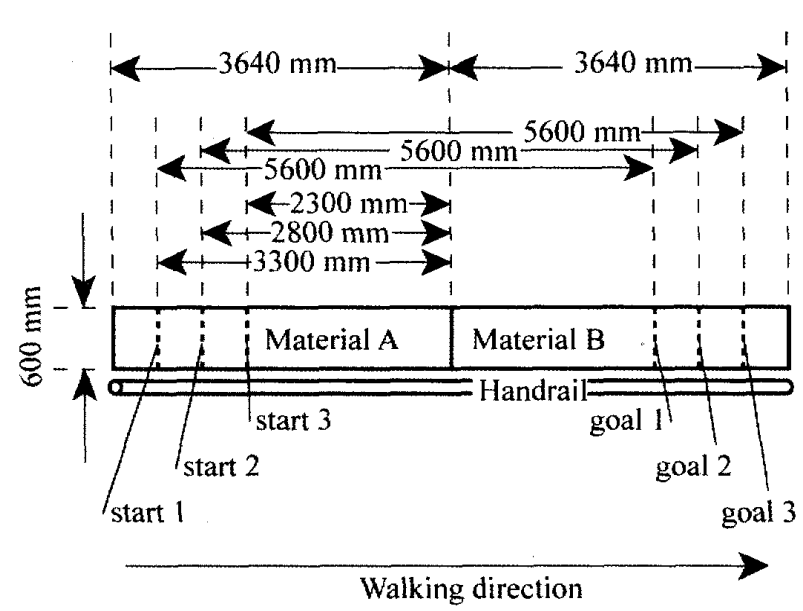

Fig.2 Setups of the walking boards, the start and corresponding goal positions, and the handrail.

Table. 1 A) Coefficient of Stiffinesses and B) Coefficient of Friction among the flooring samples.

\begin{tabular}{|c|c|c|c|}
\hline & $\begin{array}{l}\text { Polished } \\
\text { Granite }\end{array}$ & $\begin{array}{l}\text { Flamed } \\
\text { Granite }\end{array}$ & Carpet \\
\hline A. $\begin{array}{c}\text { Coefficient of } \\
\text { Friction }\end{array}$ & 0.38 & 0.91 & 0.88 \\
\hline B. Coefficient of & 0.67 & 0.60 & 0.31 \\
\hline
\end{tabular}

と記す）。また正答率の比較対象としてカーペット タイル（東りGA4002, 以下『カーペット』と記 す）を実験用の床仕上げ材として用いた。前者2つ の素材は建築の現場において，意匠性及び耐久性， 耐食性などの面からよく用いられている素材であり， 後者の素材は先行研究 (7)において弾性の高い石など の素材に対して, 従来の誘導ブロックと同等に識別 できた素材である。これら 3 種の床仕上げ材をそれ ぞれ $3640 \mathrm{~mm} \times 600 \mathrm{~mm}$ ずつの合板に敷設し，実験で用 いるテストピースとした，実験時にはこれらのテス トピースのうち 2 種を前半部と後半部としてランダ ムに組み合わせ，全長 $7280 \mathrm{~mm}$ の歩行路として提示 した（図 2）。なお，前半部と後半部が同じ床仕上 げ材の組み合わせを提示するために，各床仕上げ材 のテストピースは 2 種類ずつ作成した．また，各床 仕上げ材の厚みには若干の差があったため, 歩行路 面に段差が生じないように各床仕上げ材を敷設した 合板の厚みを調整し境界部で段差が生じないように した.
実験で用いた床仕上げ材の摩擦は，クーロンの法 則 $[\mathrm{F}=\mu \mathrm{N}]$ に従い三次元動態計測装置 VICON612(0xford Metrics) と床反力計(AMII)を用いて 推定した。一般的に路面の “滑りやすさ” の評価に は，（財）全国タイル検査・技術協会などで測定さ れているC.S.R. 值を用いることが多いが (10)，本研究 の目的は床面素材そのものの評価ではないことから 摩擦係数を用いることとした．また床仕上げ材の弾 性は，(社) 日本道路協会が定める弾力性試験方法(GB 係数)を指標として定義し, 三次元動態計測装置 VICON612で計測した. 計測された各素材の摩擦係数と GB係数を表 1 に示寸.

実験において被験者は提示された歩行路上を歩行 し，前半部と後半部の床仕上げ材が同じであったか 異なっていたかを回答した. 歩行路は前半 3 種類及 び後半 3 種類, 計 9 種類の組み合わせからなるが, 前半部と後半部の境界までの距離が每試行同じであ った場合, 被験者の予見がデー夕に混ざる可能性が 考えられたそそこで被験者が歩行を開始するスター 卜地点を 3 種用意し，歩き始めてからそれぞれ $2300 \mathrm{~mm}, 2800 \mathrm{~mm}, 3300 \mathrm{~mm}$ の位置で境界部に至るよう 工夫した，その際各スタート地点で歩行する距離に 差が出ないよう，それぞれに対応したゴール地点も 設定し，歩行距離を一定とした，更に，全試行のう ち前後の素材が異なる試行と, 同じ素材の試行の割 合が全体の $50 \%$ ずつとなるよう回数を前後の素材 が異なる組み合わせは一つの組み合わせにつき 3 試 行ずつ，前後の素材が同じ組み合わせは一つの組み 合わせにつき 6 試行ずつ行い, 54 試行ずつ計 108 試行とした，提示される素材の組み合わせ及びス夕 一ト地点の提示順序は毎試行ランダムに提示した.

実験に先立ち被験者には，早稲田大学ヒ下を対象 とする研究倫理指針に基づいたインフォームドコン セントを文章と口頭で行い, 害験に参加する同意を 得た。また，実験中被験者は歩行路の進行方向右側 に設置された手すりをガイドとして歩行し，更に被 験者の進行方向左側には実験者が併進し，安全性に 十分配慮した．実験試行の開始前には予備試行を行 い，本試行での歩行動作に十分慣れてから実験試行 を行った。

每試行得られた回答から，各床面素材の組み合わ せにおける正答率を算出し，先に提示した歩行路の 素材を因子A，後から提示した歩行路の素材を因子B とした対応のある二元配置分散分析を用いて統計的 な比較を行った，主効果が有意であった際の下位検 定にはBonferroniの多重比較法を用い, 効果量 


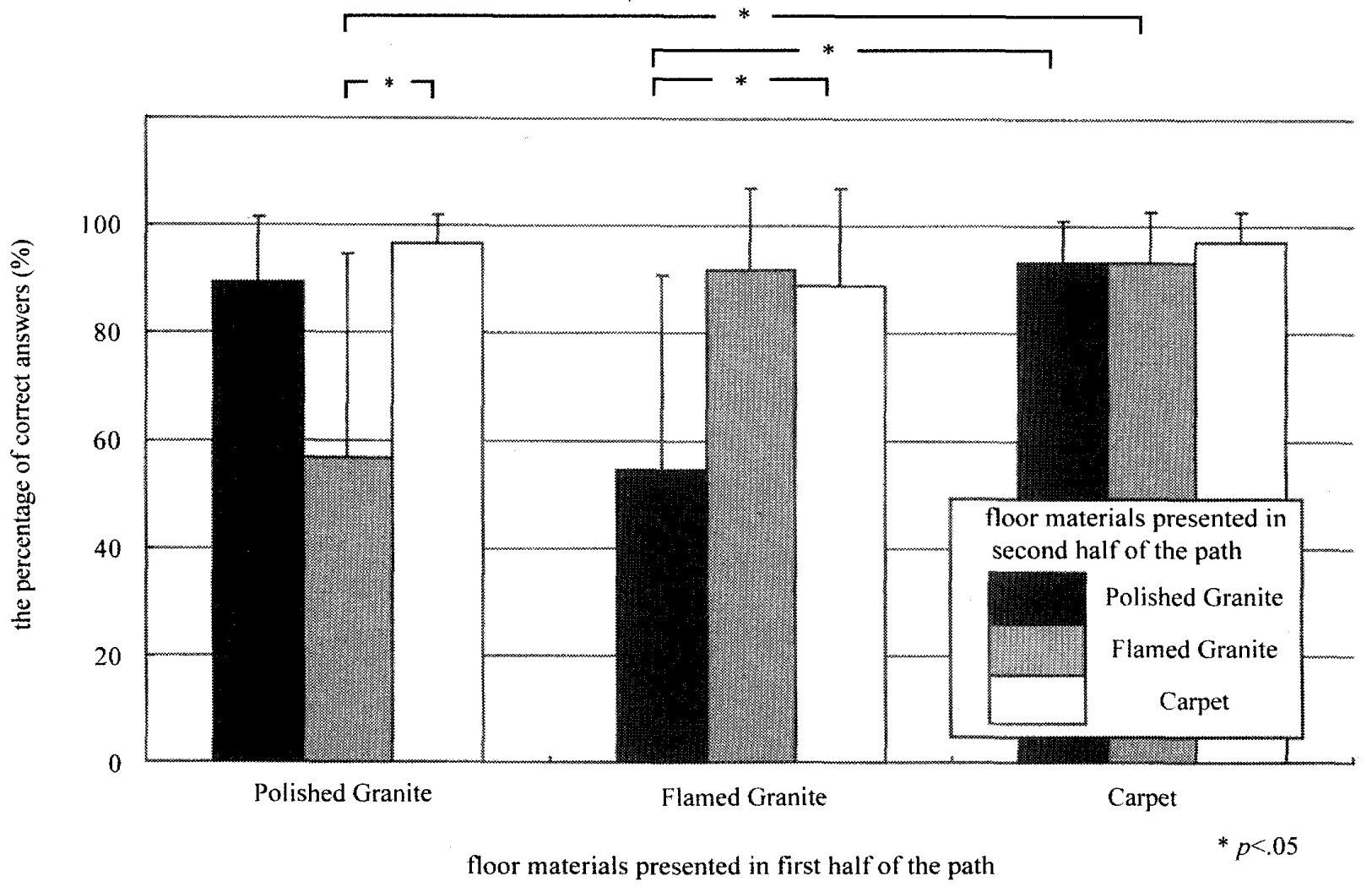

Fig.3 Average and SD percentage of correct answers among the floor materials.

（Effect Size，ES）としては偏 $\eta$ の 2 乗值を用いた. これらの統計処理にはSPSS12.0Jを用いた。

\section{3. 結果}

結果の正答率を図3に示す，図の横軸は歩行路の前 半の床面素材を示しており，3 種類の棒グラフは 各々後半の床面素材を示している. 同じ素材の場合 には被験者が「同じ」と回答した正解の比率を示し ており，異なる素材の場合には，被験者が「異な る」と回答して正解の比率, 及び標準偏差を示して いる.

先に提示した歩行路の素材を因子A，後から提示し た歩行路の素材を因子Bとした対応のある二元配置分 散分析の結果, 因子 $\mathrm{A}$ の主効果 $\left(\mathrm{F}_{(2,18)}=10.229\right.$, $\mathrm{ES}=0.532)$ ，因子 $\mathrm{B}$ の主効果 $\left(\mathrm{F}_{(2,18)}=17.700\right.$, $\mathrm{ES}=0.663)$ ，及びこれらの交互作用 $\left(\mathrm{F}_{(4,30)}=5.867\right.$, $\mathrm{ES}=0.395 ）$ が認められた，交互作用に主効果が認めら れたため，それぞれの要因に対して対応のある一元 配置分散分析を行った，その結果，先に『ミガキ』 を提示した歩行路（ $\left.\mathrm{F}_{(2,18)}=7.482, \mathrm{ES}=0.454\right)$, 先に 『バーナー』を提示した歩行路 $\left(\mathrm{F}_{(2,18)}=7.029\right.$, $\mathrm{ES}=0.439)$ ，後に『ミガキ』を提示した歩行路
$\left(\mathrm{F}_{(2,18)}=7.585, \mathrm{ES}=0.457\right)$, 後に『バーナー』を提示 した歩行路（ $\mathrm{F}_{(2,18)}=6.485$, ES =0.419) のそれぞれに関 して主効果が認められた．多重比較の結果有意差が 認められた組み合わせを図 3 中に記す。

\section{4. 考察}

本研究は，視覚障害者に対する空間の情報提示の 可能性を評価するために, 床仕上げ材間の摩擦差に 着目した。 そこで建築空間で一般的に使われている 3種類の素材を用いテストピースを作成し，そのう ちの 2 種類を前後にランダムに組み合わせた歩行路 を，視覚情報及び聴覚情報を遮蔽した被験者 10 名 に提示し，それらの識別容易性の評価を行った。

本研究で着目した摩擦の異なる床仕上げ材間（ミ ガキとバーナー）の識別率は，先行研究により有効 性が確認されている弾性の異なる床仕上げ材（カー ペット）間の識別率と比較すると有意に正答率が低 く，その差を識別出来ているとはいえない結果が得 られた，一方，弾性の異なる床仕上げ材を用いた際 には，本研究で新たに用いた摩擦の異なるいずれの 床仕上げ材との組み合わせでも 90\%以上という高い 


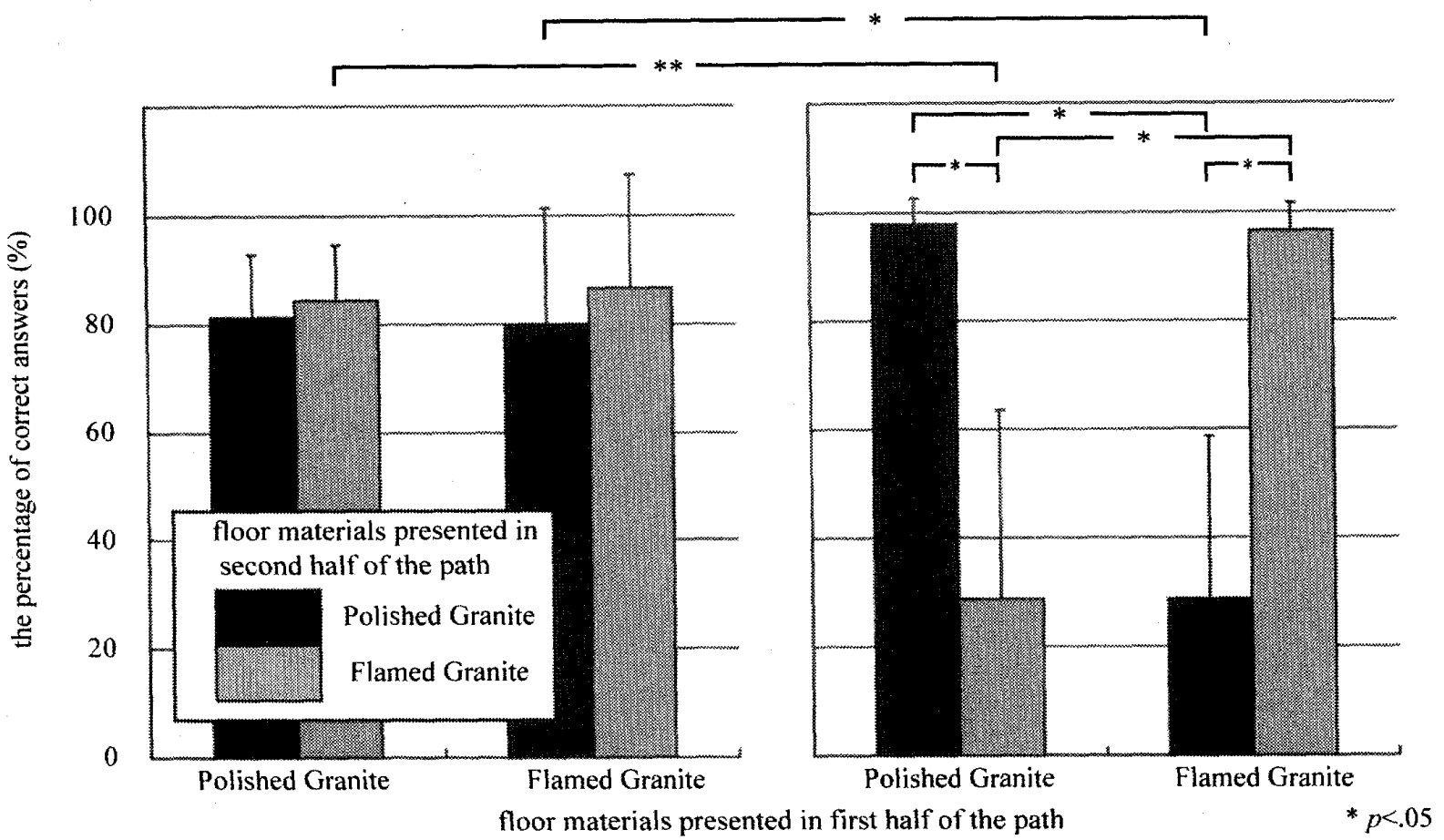

a) Participant with high percentage of correct answers $n=5$

b) Participant with low percentage of correct answers $n=5$

Fig.4 The percentage of correct answers between the floor materials with different friction.

識別率を示し，先行研究と同様その有効性が示唆さ れた。

このことから，一見するとヒトは歩行中に摩擦の 異なる床仕上げ枋の差を識別する事ができず，視覚 障害者への空間提示には適していないと考えられる. しかし摩擦の異なる床仕上げ秋間の正答率のばらつ き具合に着目するとミガキとバーナーの組み合わせ においては他の組み合わせよりも大きな標準偏差が 確認できる.このことから，被験者の中にはミガキ とバーナーの組み合わせでも高い正答率で識別でき る群と，正確に識別できない群がいる事が示唆され た．そこで各被験者個別のデー夕に着目したところ， 摩擦の異なる床仕上げ材間においても正答率が 80\%を超え，高い正答率で識別できていると考えら れる被験者群と，摩擦の異なる床仕上げ材の組み合 わせでは正答率が低い被験者群が，それぞれ5名ず つ確認された，摩擦の差も高い正答率で識別できる 群と識別できない群それぞれの正答率を図 4 に示す. なお，いずれの群でも高い正答率で識別できていた カーペットはこの図に含まなかった。

これらの被験者群の正答率間に統計的な差が認め ら机るかを確認するために，改めて先に提示した歩
行路の素材を因子 A, 後から提示した歩行路の素材 を因子 B，そして正答率の高低を因子 Cとした二要 因に対応のある三元配置分散分析を行った：その結 果，因子 $\mathrm{C}$ の主效果 $\left(\mathrm{F}_{(1,8)}=391.061, \mathrm{ES}=1.000\right)$ ，因 子 $\mathrm{A}$ と B の交互作用 $\left(\mathrm{F}_{(1,8}=15.185, \mathrm{ES}=0.925\right)$, 及 び因子 $\mathrm{A} \cdot \mathrm{B} \cdot \mathrm{C}$ の交互作用 $\left(\mathrm{F}_{(1,8)}=13.773\right.$, ES $=0.900 ）$ が確認された，更に下位検定の結果，正 答率が高い被験者群は正答率が低い被験者群よりも 有意に高い確率で摩擦の差を識別している事が確認 された（図4）。

本研究では，前半と後半の床仕上代材が同じであ る試行数と，そ扎らが巽なる試行数とが同数となる ように実験方法を工夫している。そのため被験者ら が歩行中に床仕上げ材を識別できずに適当な回答を した場合の正答率は 50\%程度となると考えられる。 このことから上述の，正答率が $80 \%$ 超えている被 験者群は，摩擦の異なる床仕上げ材を弾性の異なる 床仕上げ材間と同様に識別できていると考えられる。 一方，正答率が低い被験者群においては，摩擦の異 なる床仕上げ材間の識别率が $0 \%$ 加 10\%程度であ るが，『ミガキ』と『ミガキ』，及び『バーナー』 と『バーナー』という同素材の組み合わせではその 


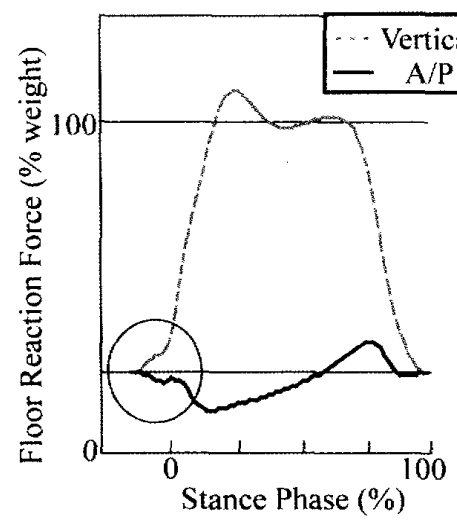

a) Participant with high

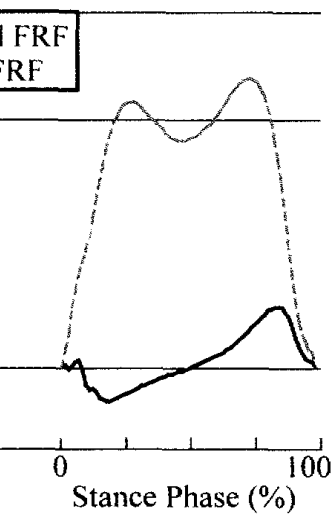

b) Participant with low percentage of correct answers percentage of correct answers

Fig.5 The percentage of correct answers among the floor materials.

正答率が $100 \%$ とっていることから，異なる素材 の差が『わからない』のではなく前後の素材が『同 じである』と認識していると考えられる.

これらのことから，正答率が高かった被験者群と， 正答率が低かった被験者群との間では，その識別方 法に何らかの違いがあり，この違いが摩擦の異なる 路面を識別するための重要な要素であると考えられ た．本研究では，床仕上げ材を識別する際に手がか りとしている聴覚情報や白杖による触覚情報を用い ず，足裹の感覚のみで識別を行うようにデザインを 行った。このことから正答率の高い群と低い群との 差は，その歩行中の歩容にあると考えられた。そこ でこれら 2 群の歩容を前述の床反力計を用いて記録 し, 歩行中の床反力の比較を行った. 記録された床 反力の波形を被験者ごとに体重で正規化し, 図5に 示す。 その結果, 正答率の高加た被験者群の床反 力は, 踵接地時以前から床反力が発生している事が 確認された（図 5a）。一方, 正答率の低かった被 験者群の床反力は, 踵接地により急激に発生してい ることが確認された（図 5b)，これらのことから 摩擦差を正確に識別できた被験者群は, 歩行中遊脚 後期に踵を地面に擦らせながら歩行しており，その 際に床仕上げ材の摩擦の違いを識別していたことが 示唆された。

本研究では摩擦の異なる床仕上げ材を, 普段床仕 上げ材の差の識別を歩行時の手がかりとすることに 慣れていない晴眼者が歩行中に足裏の感覚のみで, どの程度正確に識別できるかを定量的に示した，そ の結果, 全体の半数の被験者らは歩行中に踵を床面 に擦ることで床仕上げ材の差を非常に高い識別率で 識別できることが示唆された，このことから，白杖
や足音など，本研究では用いないように工夫した情 報も歩行時の手がかりとして用いることのできる視 覚障害者は，より正確に床仕上げ材の差を識別でき ると考えられる．そのため本研究で検証した摩擦差 や，先行研究で検証した弾性差のある床任上げ材に 関寸る知見は，これまでさまざまな理由で従来の誘 導ブロックを旉設することができなかった䈉所に， 誘導ブロックを補完する形で敷設することで，視覚 障害者の歩行空間の拡大に応用することができると 考えられる，また，本研究で検証しているような手 法は，従来の誘導ブロックのように利用しない人に とってのバリアとなる可能性が低いため，より広範 に敷設することが可能であると考えられ，従来の誘 導ブロックのような線としての誘導から，面として 安心して歩行できる空間そのものを提示できる可能 性が考えられる。

今後は，上記のような面としての歩行空間提示の 有効性を検討しつつ, 本研究で制限した項目（靴の 属性や白杖・足音情報の有無など）について客観的 に評価していきたい。

\section{5. 結 論}

本研究は, 歩行中にヒトが摩擦の異なる床仕上げ 材をどの程度正確に識別できるか，その識別容易性 を定量的・客観的に評価した，その結果，全体的に は摩擦差の識別性は弾性差の識別性よりも有意に低 いことが確認されたが，正答率が高い群と低い被験 者群の 2 群が確認され，正答率が高い群の被験者ら は，遊脚後期に踵を地面に擦ることで，弾性差と統 計的にその差が認められない範囲で識別しているこ とが明らかとなった。

\section{文献}

(1) Hideyuki IWAHASHI, Biggraphy of Seïchi Mivake (hakuro ni mukaite: miyake seüchio katarw), Okayama Japan, (1983).

(2) Japan Braille library, Report of inconvenienceness during daily life for people with visual impairment, Japan Braille library, (1993).

(3) Ministry of International Trade and Industry, Report of Fundamental Research on Standardization Relating to Tactile Tiles for Guiding the Visually Impaired -Aiming at Standardization of Patterns; National Institute of Technology and Evaluation, (2000) .

(4) Satoshi KONDO et al, Falling and fear of falling among the community dwelling elderly, The Japanese journal of occupational therapy, 33, (1999), pp.839-844. 
(5) Michiko TSUDA, Pedestrian's rad 1, Gihoudou-Shuppan, (2002), pp. 125-129.

(6) Yoshiyuki KOBAYASHI etal, The Effect of Tactile Ground Surface Indicators to the Gait of Human with Normal Vision, Transactions of the Japan Society of Mechanical Engineers, Series C, Vol 69, No. 681, (2003), pp. 86-92.

(7) Yoshiyuki KOBAYASHI et al, Gait Analysis of People Walking on Tactile Ground Surface Indicators, IFEE Transactions on Neural Systems and Rehabilitation Engineering, Vol. 13, No. 1, (2005), pp. 53-59.

(8) Yoshiyuki KOBAYASHI et al, The Effect of Tactile Ground Surface Indicators to the Gait of Elderly with Normal Vision, Transactions of the Japan Society of Mechanical Engineers, Series C, Vol 72, No. 720, (2003),pp. 234-239.

(9) Yoshiyuki KOBAYASHI et al, How Aocurately People can Discriminate the Differences of Floor Materials with Various Elasticities, IEEE Transactions on Neural Systems and Rehabilitation Engineering, Vol. 16, No. 1, (2008), pp. 99-105.

(10) Hidenori ONO, Floor Slipperiness Safety, Comfort, and the Basic Measure, Construction Finishing Techniques, Vol.20, No.240, (1995), pp.35-62. 